\title{
Integrated Academic Writing Assessment Model to Support The Implementation of OBE Curriculum
}

\author{
Hamamah $^{1}$, Yulia Hapsari ${ }^{1}$, Ive Emaliana ${ }^{1}$, Putu Dian Danayanti Degeng ${ }^{1}$ \\ ${ }^{1}$ Faculty of Cultural Studies, Universitas Brawijaya
}

\section{INFO ARTIKEL}

\section{Riwayat Artikel:}

Diterima: 20-06-2020

Disetujui: 23-07-2020

\section{Kata kunci:}

Academic Writing Assessment model;

outcome-based Education (OBE); ADDIE;

learning outcomes;

student's abilities,

\section{Alamat Korespondensi:}

Hamamah

Faculty of Cultural Studies

Universitas Brawijaya

Jl. Veteran Malang

E-mail: hamamah@ub.ac.id

\section{ABSTRAK}

Abstract: Implementation of outcome-based Education (OBE) in Indonesia has been urged since 2019. It primes to the need of some adjustments in the higher education curriculum. In Academic writing classes in which English is served as a foreign language, implementation of $\mathrm{OBE}$ principles imposes issues as assessment must measure all abilities, skills, and knowledge targeted in the learning outcomes. The challenge escalate with large size classes that lead to a less optimum assessment given to learners' writing. The need of writing assessment model that obeys OBE principles and facilitates academic writing teachers in coping with complication in providing quality assessment to scads of students in Indonesia is of a paramount importance. Yet, studies aimed at meeting the need are barely conducted. This research, therefore, designs writing assessment model which can (1) measure the expected learning outcomes, (2) monitor student's abilities, skills and knowledge with regard to their individual learning pace, (3) assist the teachers of writing classes to comprehensively provide rigorous assessment to lots of students. ADDIE (Analysis, Design, Development, Implementation, and Evaluation) model is employed to reach the research objectives. As the whole process is still on going, this article presents the Analysis and Design stages of the study. It elaborates underlying considerations of the proposed assessment model by reviewing previous studies related to writing assessment and OBE assessment in writing. The descriptions of the illustrated assessment model are presented to provide vivid view of how the assessment model works.

Abstrak: Implementasi Pendidikan Berbasis Hasil (OBE) di Indonesia telah digalakkan sejak tahun 2019. Hal tersebut didorong oleh perlunya beberapa penyesuaian dalam kurikulum pendidikan tinggi. Dalam kelas menulis akademik dimana bahasa Inggris disajikan sebagai bahasa asing, penerapan prinsip-prinsip OBE memberlakukan masalah karena penilaian harus mengukur semua kemampuan, keterampilan, dan pengetahuan yang ditargetkan dalam hasil pembelajaran. Tantangan meningkat dengan kelas berukuran besar yang mengarah pada penilaian yang kurang optimal yang diberikan pada hasil tulisan peserta didik. Perlunya model asesmen menulis yang menganut prinsip OBE dan memfasilitasi guru kepenulisan akademik dalam menghadapi kesulitan dalam memberikan asesmen berkualitas kepada siswa di Indonesia menjadi sangat penting. Namun, studi yang ditujukan untuk memenuhi kebutuhan tersebut hampir tidak pernah dilakukan. Oleh karena itu, penelitian ini merancang model penilaian menulis (1) mengukur hasil belajar yang diharapkan, (2) memantau kemampuan, keterampilan dan pengetahuan siswa terkait dengan kecepatan belajar individu mereka, (3) membantu guru kelas menulis untuk memberikan penilaian yang cermat secara komprehensif kepada siswa. banyak siswa. Model ADDIE (Analysis, Design, Development, Implementation, and Evaluation) digunakan untuk mencapai tujuan penelitian ini. Karena keseluruhan proses masih berlangsung, artikel ini menyajikan tahapan Analisis dan Desain dari studi tersebut. Tulisan ini menguraikan pertimbangan yang mendasari model penilaian yang diusulkan dengan meninjau penelitian sebelumnya terkait dengan penilaian menulis dan penilaian OBE secara tertulis. Deskripsi model asesmen bergambar disajikan untuk memberikan gambaran yang jelas tentang cara kerja model asesmen. 
As ministry of education has release new curriculum guideline, higher education tries to organize and establish how teaching and learning process should be approached by every department, for (Banegas, 2019) highlight that authenticated curricula in language teaching is frequently top-down and hierarchical. It is acknowledged that the application of curriculum primarily becomes lecturers' responsibility and its success relies on their knowledge and ownership of what the curriculum has proposed (Huizinga et al., 2014). This is also true for English language teaching (ELT) program, a new curriculum teaching materials, strategies, and assessment. In response to the calls to incorporate the changing curriculum, academic writing course assessment needs to be examined to meet the appropriateness of the new curriculum, which is under outcome-based education (OBE).

OBE is a learning method that defines learning outcomes or outcomes at the beginning of the learning process, designing curriculum with learning activities, linking the process of teaching and learning activities with predetermined results, and evaluating the level of student success in accordance with the determined results (Crespo et al., 2010). In Indonesian higher education context, $\mathrm{OBE}$ is defined as education process that focused at achieving the certain specified concrete outcome (results oriented knowledge, ability and behavior) (Ditjen Belmawa Kemenristekdikti, 2018). Starting with a clear picture of the important abilities that students can do at graduation, the OBE principle continues with the planning of How to make the student achieve the outcomes contained in the curriculum. At the instructional level, teaching and learning activities should be able to measure what the student has achieved through the assessment process (Ditjen Belmawa Kemenristekdikti, 2018). In the OBEbased curriculum, the objectives that must be achieved or learning outcomes are identified first, then the planning of learning and assessment methods is adjusted according to the outcome (Spady, William, 1994). To implement OBE principles in courses, learning should be carried out with a student-centered learning approach in which the assessment measures students' knowledge, ability and behavior progress (Ditjen Belmawa Kemenristekdikti, 2018). The assessment should embrace at least formative and summative assessments as suggested by (Ditjen Belmawa Kemenristekdikti, 2018).

To follow up, in 2019 Ditjen Belmawa Kemenristekdikti issued a guideline on OBE practice to be implemented by all higher education institutions in Indonesia. One of the motives for its implementation is to attain international standard of quality in higher education in Indonesia which is measured through international accreditation or certification process. OBE is defined as a process that involves the restructuring of curriculum, assessment and reporting practices in education to reflect the achievement of high order learning and mastery rather than accumulation of course credits (Ditjen Belmawa Kemenristekdikti, 2018). As a follow-up, universities in Indonesia need to adjust the principles and regulate the technicalities of the teachinglearning process based on OBE principles.

OBE has increased repute acknowledgement internationally to advance education policy and reform. In the process of planning academic writing course syllabus, the learning outcomes is stressed and has been decided (Akir et al., 2012), namely what are expected from studying after students graduated to provide them essential capabilities and skills prior to become English teachers. One strategy of contributing components delivery under OBE is by blended learning that is accomplished via technology aids or through online (Gupta \& Dutta, 2020). This is accomplished to find new knowledge and promote active learning during mastering writing skill. The ability to write scientific papers properly and correctly is absolutely required by academics and students either in undergraduate, postgraduate or doctoral level. In the Regulation of the Minister of Research and Technology of Higher Education Number 50 of 2018 academics and students are encouraged to publish scientific papers in national and international reputable journals as an effort to develop science and technology and increase the nation's competitiveness.

Addressing the government appeal of international publication for all academics and university students, and taking the OBE principles into account, designing academic writing courses which enforce OBE principles has become a paramount importance in the effort of improving students' ability in scientific writing in English, not to mention that English is a foreign language in Indonesia. Writing in a second/foreign language covers various factors that affect the result of the composition (Obeid, 2017). During their writing process, foreign language learners have to deal with cognitive process ( $\mathrm{Li}, 2008)$ and certain mastery of the target language (Allen \& Katayama, 2016). Thus, teachers are expected to provide more feedback on various aspects of student writing so that the learning process to write in English can provide significant results (Ariyanti \& Fitriana, 2017). A large class sizes is one of the factors that can add more complication in mastering writing in a target language (Ghalib \& Al-Hattami, 2015). In Indonesia, the number of learners in a class is usually quite large and is not proportional to the number of teachers available as well as the limited time for each class meeting (Ariyanti \& Fitriana, 2017). This causes the lecturers to have difficulty and less able to provide maximum feedback (to help the students) in writing (in English as a foreign language) (Yustiana, 2015).

Writing is seen to be a complicated skill to master since it concerns with various aspects which are not naturally subsequent or chronological, instead, they are more as aspects which come with various indicators (Obeid, 2017). In learning writing, it is necessary for learners to be informed and be aware of their progress in achieving the intended learning outcome and of criteria that they need to meet to be successful (Hawe \& Parr, 2013). In a teaching or instructional context, both teachers and learners should be able to monitor the learners' progress toward the intended learning objectives (Hattie \& Timperley, 2007). They should be able to generate meaningful feedback from the assessment (Hawe \& Parr, 2013). 
Feedback is mainly aimed at giving correction and constructive input (Hawe et al., 2008) as it is understood as “information provided by an agent (e.g. teacher, peer, book, parent, self, experience) regarding aspects of one's performance or understanding..." (Hattie \& Timperley, 2007). In regard to writing, effective feedback is the one which focuses on the purpose of writing, the idea organization, and the use of the language. Thus, quality feedback is really determined by the knowledge of the teachers especially the one related to subject and its pedagogical knowledge as well as the understanding about the context and the student(s) (Timperley \& Parr, 2009). In relation to this, Tsui \& Ng (2000), in their study in Hong Kong, found out that all of the students as their research participants favor feedback provided by their teachers to the one given by their peer. They believe that only the teachers who can provide them with quality feedback as they have the qualifications to do so.

The learners' high expectation on getting a quality feedback from their teacher in a writing class may end up with disappointment when the class takes in a large number of students. The teacher will be overwhelmed with the students writing. Overburdened teachers are barely able to provide quality feedback. As a practical solution, many teachers opted to generate peer feedback from peer assessment activities. Hansen \& Liu (2005) identified peer feedback as an activity in which learners play roles as information sources and partners to interact as if they are doing what normally carried out by teacher, mentor, or supervisor in giving comments and critiques as feedback for their peers' works either in written or spoken forms.

Strong and positive points of peer feedback are argued by many scholars. Sadler ( 1998) highlighted how essential and influential peer feedback and learners' self-monitoring are in the learners' improvement. It is in line with Keen (2010) who pointed out the benefits of peer feedback promoting writer's improvement in their writing work. By doing peer feedback, learners who provide inputs for other learners can get a better understanding and be more critical that eventually will lead to their better mastery in writing since they need to deal with various ways of how other learners work on the same or similar tasks, different difficulties experienced by other learners, and numerous effort done by other learners to bring the best that they can do to be successful.

Aforementioned discussion show that abundant research and investigations pertinent to assessment in writing have been conducted to reveal various aspects of the assessment seen from various point of views. Regardless the teachers awareness that assessment is fundamental in any writing classroom and is essentially crucial to the learners' improvement academically (White, 2009), a variety of context-related issues can affect teachers in giving assessment to students' writing. The issues were further identified by (Ruecker et al., 2014) as the availability of resources, the place of writing in English in different contexts, institutional mandates about how writing is taught and assessed, and teachers' workloads. The emergence of the issues may cause an ununiformed assessment that can lead to the loss for students in some aspects including motivation, and confidence. Therefore, teachers' knowledge and ability in creating fair assessments which inform the learners about their progress in learning is an unavoidable quality. Teachers should be able to develop assessment criteria and scoring rubrics as well as considering the feasibility of conducting the assessment process due to certain situations that they encounter.

\section{METHODS}

This present research employed ADDIE (Branch, 2009) model for the research method. The ADDIE model has a main stages; Analysis, Design, Development, Implementation (trial), and Evaluation. ADDIE is suitable to be used to develop an assessment model in this study because this model is strongly influenced by Robert Gagné which includes aspects of psychology, cognitive, and educational constructivism. Considering the stages in the ADDIE model, this research process will take 3 years to be completed. This initial year will comprise the Analysis, Design, and Development stages. While, this article covers the Analysis and Design stages since the Development stage is still being carried out.

The Analysis stage in this study wraps us the mapping of needs, student groups, context and learning content. The analysis process is carried out through 1) evaluation of the learning process of the Academic Writing course in the form of input from lecturers and students, and 2) evaluation of the existing automatic assessment system. Next, on the Design stage, the assessment model is designed for Academic Writing course which implements Outcome-based Education principles highlighting on the student-centered learning and Process Writing.

\section{RESULTS AND DISCUSSION}

The process of developing the integrated assessment model of academic writing for OBE reported in this article involved 2 out of the 5 phases in the ADDIE Model, namely Analysis and Design.

\section{Analysis}

The analysis process begins with a reviewing some aspects: (1) the principles of assessment in the OBE curriculum, (2) the aspects to be considered in assessing academic writing, and (3) problems in academic writing instruction in Indonesian context. 
On OBE assessment principles, there are several points to be considered. The assessment must check all expected abilities stated as the outcome of learning (Malan, 2000). The assessment must measure the intended skills and knowledge, be reliable, should not be interfered by unrelated factors, should expand the students' proficiency, be explicit, provide opportunity to learn essential matters, and captures students' individual uniqueness (Karim \& Yin, 2013). Additionally, (Willis \& Kissane, 1995) recommended standard-referenced assessment and portfolio for assessment in OBE.

On aspects to be taken into account in assessing academic writing, some considerations were taken. The assessment should provide meaningful input for the students, measure writing skills and knowledge, which include content, organization, discourse, syntax, vocabulary, mechanics, plagiarism (Hattie \& Timperley, 2007). The assessment should provide the opportunity for students to get feedback from various parties, and involve students' active participation (Hawe et al., 2008; Hawe \& Parr, 2013).

On problems in writing instructions in Indonesian context, in general, there are two main problems: the students' writing problems and the difficulties of teachers provide proper feedback for the students' writing due to the limited time and the many number of students (Ariyanti \& Fitriana, 2017). These information, then used as a basis for formulating the design of the assessment model in accordance with OBE principles that can be applied in Academic Writing learning.

\section{Design}

After considering the results of the analysis in the previous phase, we came up with some considerations for developing the integrated writing assessment model:

1. This integrated writing assessment model, by considering OBE principles, needs to adapt the process-writing stages, namely outlining, drafting, peer-reading and editing, conferencing, and final composition.

2. Accommodating the many aspects of writing and the provision of feedback as a part of assessment in writing, this integrated writing assessment model needs to provide a means for interaction between learners (to provide feedback) so that student-centered learning can be realized.

3. To monitor the learners' progress in achieving the expected learning outcome as a part of OBE practices, this integrated writing assessment model needs to accommodate the needs of portfolio documentation. The paper-based portfolio is currently considered not easily accessible for communication and discussion. If a portfolio is provided, it will make it easier for teachers and learners because it can accommodate various formats and media that can help the writing learning process.

4. Automated writing evaluation is really a potential solution to provide better feedback in academic writing courses in which large number of students made the teachers has only limited time to assess the students' progress. An online writing assessment model can provide an assessment that can be carried out by the system automatically. Then the application needs to be designed to be able to integrate with the grammar and plagiarism checker application platform so that it makes it easier for lecturers to carry out an integrated assessment.

By considering these notes, the integrated writing assessment model designed for academic writing course which is conducted under OBE principles can be described in Figure 1. From Figure 1 it can be seen that there are several steps in the process writing approach. According to (Nabhan, 2016), the process writing approach consists of (1) pre-writing, (2) planning, (3) drafting, (4) reflecting, (5) peer or tutor reviewing, (6) revising, and (7) editing/proofreading. This integrated writing assessment model uses the steps in the process writing approach with a slight modification at the tutor reviewing stage as the lecturer or tutor can provide feedback and direction more than once during the writing process. 


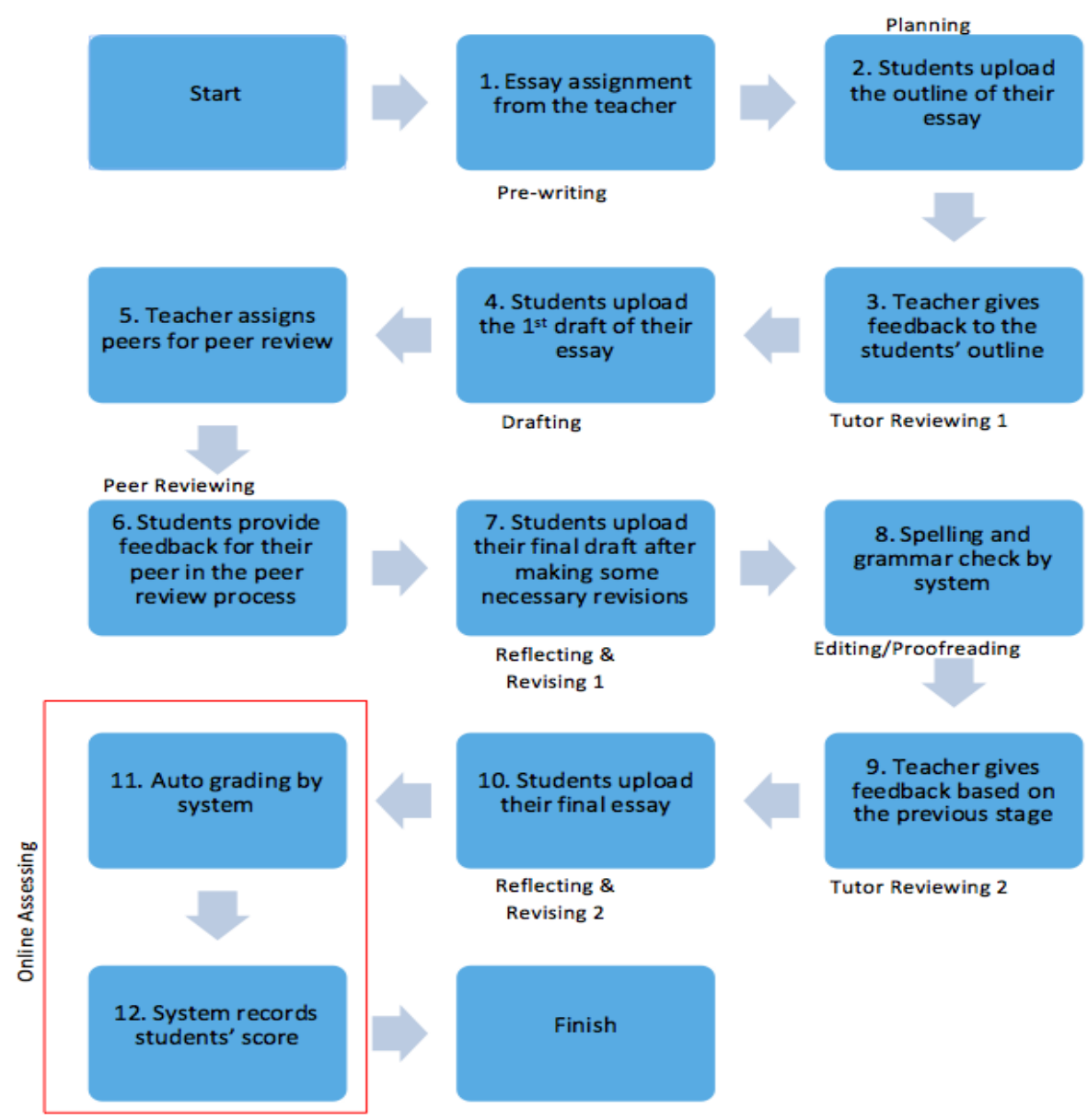

Figure 1. Design of the Online Integrated Writing Assessment Model for OBE

\section{Pre-writing}

In this stage, students are intended to be able to carry out activities before starting writing. This activity includes the process of finding ideas, ideas, or themes, gathering information relevant to the writing theme, and creating a flow of thought. Pre-writing can be done freely by students, students can brainstorm, write freely, and read references. After that, the next step is for students to begin organizing the ideas they have obtained using mind mapping, clustering, and branching.

Pre-writing in this case is meant in stages 1 and 2. Stage 1, the lecturer gives a writing assignment in accordance with the learning design first, this aims to direct students to do pre-writing activities. The lecturer provides directions and provisions for the general theme and provides examples of ideas that students can use. Students independently choose and collect writing ideas and continue by looking for references that can support writing these ideas.

\section{Planning}

In stage 2, students arrange the ideas they get from the pre-writing results with a writing framework or outline which is then uploaded into the system. The uploaded outline contains at least the topics to be discussed and several other chapters, such as the following example. 


\begin{tabular}{|ll|}
\hline Topic: & \\
Chapter I & \\
Background & $:$ \\
Gap & $:$ \\
Problem & $:$ \\
Significance & $:$ \\
& \\
Chapter II & $:$ \\
Theory & $:$ \\
Supporting Theory & $:$ \\
Previous Studies & $:$ \\
& \\
Chapter III & $:$ \\
Research Design & $:$ \\
Data Source & $:$ \\
Data Collection & $:$ \\
Data Analysis & $:$ \\
\end{tabular}

Figure 2. Planning Stage of the Online Integrated Writing Assessment Model for OBE

\section{Drafting}

Students start drafting at stage 4 after getting feedback from the lecturer regarding the writing framework. In the drafting process, students develop their writing ideas from a writing framework in the form of points to be more comprehensive. Students develop ideas in pre-writing strategies, narrow broad focus, and omit or add information. At this stage, students write in full from the beginning to the end of the writing by considering the coherence of one point with another from the writing framework.

\section{Peer or tutor reviewing}

The review process and giving feedback are carried out several times, namely in stage 3 (tutor reviewing 1) feedback is given after the student has created a writing framework, stage 6 (peer reviewing) feedback is given from and to fellow students, and stage 9 (tutor reviewing 2) feedback is given by the lecturer by considering the results of the spelling and grammar correction of the system. Feedback from lecturers and friends can be in the form of input and suggestions orally or in writing.

\section{Reflecting \& Revising}

This stage is intended to give students time to revise their writing after being given feedback by lecturers and fellow students. In this context, reflection means taking a short break before returning with a fresh mind. Reflection time allows students to see gaps in writing assignments (Nabhan, 2016). In the development procedure, this stage is described in stages 7 and 10.

\section{Editing/proofreading}

Editing and proofreading are often considered the same thing in the writing process, but they are different activities. Editing or editing involves reviewing content, writing style, structure and writing organization, while proofreading or proofreading is an activity to double-check errors in grammar, word form, spelling and punctuation (O'Brien, 2015). In the data collection stage in this study, this process is at stage 8 . This stage uses a system that has been developed to provide more accurate results for spelling and grammar errors so that in this case it can be concluded that stage 8 which is carried out by the system only covers parts proofreading, but the editing process is carried out by the lecturer at stage 9 .

\section{CONCLUSION AND SUGGESTIONS}

Arranging writing courses by implementing OBE principles has become a very crucial matter in the effort to improve students' ability in scientific writing in English, considering that English is a foreign language in Indonesia. Writing in a second or foreign language imposes numerous factors affecting the composition result. Moreover, a large number of students in class contribute another challenging factor that can add more complication in improving students writing skill. Ideal practice of teachers providing quality feedback for students in a large writing class is almost impossible to be conducted. As a solution, an OBE-based integrated writing assessment model that employs automated writing evaluation which facilitates teachers of writing classes in giving feedback to a large number of students in a shorter time is proposed to be further developed into an online application. 


\section{ACKNOWLEDGEMENT}

The authors would like to express their appreciation for the support of the sponsors with Institute of Research and Community Service (LPPM) Universitas Brawijaya for Doktor Non Lektor Kepala Project No. 0751/UN10.F12/PN/2020

\section{REFERENCES}

Akir, O., Eng, T. H., \& Malie, S. (2012). Teaching and Learning Enhancement Through Outcome-Based Education Structure and Technology e-Learning Support. Procedia - Social and Behavioral Sciences, 62, 87-92. https://doi.org/10.1016/j.sbspro.2012.09.015

Allen, D., \& Katayama, A. (2016). Relative Second Language Proficiency and the Giving and Receiving of Written Peer Feedback. System, 56, 96-106. https://doi.org/10.1016/j.system.2015.12.002

Ariyanti, A., \& Fitriana, R. (2017). EFL Students' Difficulties and Needs in Essay Writing. 158(Ictte), 111-121. https://doi.org/10.2991/ictte-17.2017.4

Banegas, D. L. (2019). Language Curriculum Transformation and Motivation Through Action Research. Curriculum Journal, 30(4), 422-440. https://doi.org/10.1080/09585176.2019.1646145

Branch, R. M. (2009). Approach, Instructional Design: The ADDIE. In Statistical Field Theor (Vol. 53, Issue 9). https://doi.org/10.1007/978-0-387-09506-6

Crespo, R. M., Najjar, J., Derntl, M., Leony, D., Neumann, S., Oberhuemer, P., Totschnig, M., Simon, B., Gutiérrez, I., \& Delgado Kloos, C. (2010). Aligning Assessment with Learning Outcomes in Outcome-Based Education. 2010 IEEE Education Engineering Conference, EDUCON 2010, 1239-1246. https://doi.org/10.1109/EDUCON.2010.5492385

Ghalib, T. K., \& Al-Hattami, A. A. (2015). Holistic Versus Analytic Evaluation of EFL Writing: A Case Study. English Language Teaching, 8(7), 225-236. https://doi.org/10.5539/elt.v8n7p225

Gupta, S., \& Dutta, P. K. (2020). Topic Objective and Outcome: Performance Indicators in Knowledge Transfer Through inDepth Curriculum Content Analysis. Procedia Computer Science, 172(2019), 331-336. https://doi.org/10.1016/j.procs.2020.05.053

Hansen, J. G., \& Liu, J. (2005). Guiding Principles for Effective Peer Response. ELT Journal, 59(1), 31-38. https://doi.org/10.1093/elt/cci004

Hattie, J., \& Timperley, H. (2007). The Power of Feedback. Review of Educational Research, 77(1), 81-112. https://doi.org/10.3102/003465430298487

Hawe, E., Dixon, H., \& Watson, E. (2008). Oral Feedback in the Context of Written Language. Australian Journal of Language and Literacy, 31(1), 43-58.

Hawe, E., \& Parr, J. (2013). Assessment for Learning in the Writing Classroom: An Incomplete Realisation. Curriculum Journal, 25(2), 210-237. https://doi.org/10.1080/09585176.2013.862172

Huizinga, T., Handelzalts, A., Nieveen, N., \& Voogt, J. M. (2014). Teacher Involvement in Curriculum Design: Need for Support to Enhance Teachers’ Design Expertise. Journal of Curriculum Studies, 46(1), 33-57. https://doi.org/10.1080/00220272.2013.834077

Karim, N. A.-H. A. K., \& Yin, K. Y. (2013). Outcome-Based Education: An Approach for Teaching and Learning Development. Journal of Research, Policy \& Practice of Teachers \& Teacher Education, 3(1), 26-35.

Keen, J. (2010). Strategic Revisions in the Writing of Year 7 Students in the UK. Curriculum Journal, 21(3), 255-280. https://doi.org/10.1080/09585176.2010.504574

Li, X. (2008). Cognitive Transfer and English writing. English Language Teaching, 1(1), 113-115. https://doi.org/10.5539/elt.v1n1p113

Malan, S. (2000). The "New Paradigm" of Outcomes-Based Education in Perspective. Journal of Family Ecology and Consumer Sciences /Tydskrif Vir Gesinsekologie En Verbruikerswetenskappe, 28(1), $22-28$. https://doi.org/10.4314/jfecs.v28i1.52788

Nabhan, S. (2016). The Process Approach to Improve Students' Writing Ability In The Process Approach to Improve Students' Writing Ability In English Education Department University of PGRI Adi Buana Surabaya. Jembatan Merah Jurnal Pengajaran Bahasa Dan Sastra, 13(June 2016), 0-15.

O’Brien, J. (2015). Consciousness-raising, Error Correction and Proofreading. Journal of the Scholarship of Teaching and Learning, 15(3), 85-103. https://doi.org/10.14434/josotl.v15i3.13284

Obeid, R. (2017). Second Language Writing and Assessment: Voices from Within the Saudi EFL Context. English Language Teaching, 10(6), 174. https://doi.org/10.5539/elt.v10n6p174

Ruecker, T., Shapiro, S., Johnson, E. N., \& Tardy, C. M. (2014). Exploring the Linguistic and Institutional Contexts of Writing Instruction in TESOL. TESOL Quarterly, 48(2), 401-412. https://doi.org/10.1002/tesq.165

Sadler, D. R. (1998). Formative Assessment: Revisiting the territory. International Journal of Phytoremediation, 21(1), 77-84. https://doi.org/10.1080/0969595980050104 
Spady, William, G. (1994). Available from. The American Association of School Administrators.

Timperley, H. S., \& Parr, J. M. (2009). What Is This Lesson About? Instructional Processes and Student Understandings in Writing Classrooms. Curriculum Journal, 20(1), 43-60. https://doi.org/10.1080/09585170902763999

Tsui, A. M. Y. B. M., \& Ng, M. (2000). Do Secondary L2 Writers Benefit from Peer Comments ? 9(2).

White, E. (2009). Are You Assessment Literate? Some Fundamental Questions Regarding Effective Classroom-Based Assessment. OnCUE Journal, 3(1), 3-25. http://jaltcue-sig.org/files/OnCUE/OCJ3-1articles/OCJ3-1-White-pp3-25.pdf Willis, S., \& Kissane, B. (1995). Outcome-Based Education a Review of the Literature. In Education Department of Western Australia (Vol. 1, Issue 3).

Yustiana, D. (2015). Penilaian Otomatis Terhadap Jawaban Esai Pada Soal Berbahasa Indonesia Menggunakan Latent Semantic Analysis. Seminar Nasional “Inovasi Dalam Desain dan Teknologi” - IDeaTech 2015, 123-130. 